\title{
New host records for cotton leaf curl Gezira virus: capsicum and melon in Egypt
}

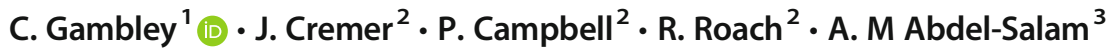

Received: 5 October 2019 / Accepted: 20 December 2019 / Published online: 3 January 2020

(C) Australasian Plant Pathology Society Inc. 2020

\begin{abstract}
Cotton leaf curl Gezira virus (CLCuGeV), in association with a DNA-beta satellite, is reported as a causal agent of cotton leaf curl disease. This study reports $\mathrm{CLCuGeV}$ detection in field samples of Capsicum annuum and Cucumis melo from Egypt and represents an expansion of the virus host range beyond the Malvaceae family to the two plant families, Solanaceae and Cucurbitaceae.
\end{abstract}

Keywords Begomovirus · Beta-satellite $\cdot$ DNA-A $\cdot$ Capsicum annuum $\cdot$ Cucumis melo $\cdot$ Potyvirus $\cdot$ squash leaf curl virus $(\mathrm{SqLCV}) \cdot$ zucchini yellow mosaic virus $(\mathrm{ZYMV}) \cdot$ papaya ringspot virus $(\mathrm{PRSV}) \cdot$ potato virus $Y(\mathrm{PVY})$

Begomoviruses are considered one of the major emerging viral threats to crop production worldwide (Mansoor et al. 2006; Varma and Malathi 2003). Cotton leaf curl disease (CLCuD) is caused by a complex of different begomoviruses and DNA-beta satellite molecules. The disease was first recorded in Africa in the 1920s, in Pakistan and India during the 1990s and most recently in 2010, in China (Cai et al. 2010). The disease is reported from Pakistan, India, Sudan, Egypt, China, Tanzania, Malawi, Nigeria and South Africa (AbdelSalam 1999; Briddon 2003; Cai et al. 2010; Mansoor et al. 1999; Mansoor et al. 2003; Malathi et al. 2003). CLCuD is responsible for serious economic losses to cotton production in many regions around the world, particularly on the Indian subcontinent. For example, CLCuD cost the Pakistan industry an estimated US\$5 billion between 1992 and 1997 (Briddon et al. 2001). In Sudan during the 1950's the disease caused yield losses of up to $40 \%$ (Malathi et al. 2003).

The number of begomoviruses causing CLCuD has risen from only a few species in 1992 to at least 30 species in 2008 (Fauquet et al. 2008). This includes cotton leaf curl Gezira

C. Gambley

Cherie.gambley@daf.qld.gov.au

1 Department of Agriculture and Fisheries, 4 Roessler Ave, Applethorpe, Australia

2 Department of Agriculture and Fisheries, Dutton Park, Brisbane, Australia

3 Department of Plant Pathology, Faculty of Agriculture, Cairo University, Giza 12613, Egypt virus $(\mathrm{CLCuGeV})$ which was first reported from Africa in 2002 (Idris and Brown 2002; Idris et al. 2005). Other begomoviruses associated with CLCuD such as cotton leaf curl Kokhran virus are known to have vegetable crop hosts such as tomato and capsicum (Nateshan et al. 1996). However, the host status of $\mathrm{CLCuGeV}$ amongst nonmalvaceous vegetable crop species was unknown. This study was aimed at investigating solanaceous and cucurbit species as hosts of CLCuGeV. The detection of two new host species of $\mathrm{CLCuGeV}$, capsicum and melon, is reported.

A range of vegetable and melon samples were collected from a field trial site in Ashmoun, Egypt, May 2010 and indexed for begomoviruses and associated DNA-beta satellites. The samples included those from melon (Q2540, Q2541, Q2542 and Q2545 - Cucumis melo), cucumber (Q2521, Cucumis sativus), squash (Q2517, Cucurbita pepo), chilli (Q2537 and Q2539, Capsicum spp.) and capsicum (Q2535, Capsicum annuum), and all showed symptoms of infection of either a begomovirus and/or a potyvirus. All samples tested positive for one or both of these virus genera. No samples had symptoms typical of the DNA-beta satellite usually associated with $\mathrm{CLCuD}$ (i.e severe cupping of leaves or presence of enations on leaves) (Amin et al. 2011).

To do the virus identifications, samples were first wiped clean of insects prior to processing to avoid any potential contamination, then total nucleic acid extracts (TNAEs) were prepared using a Biosprint DNA Plant Kit as per manufacturer's instructions (Qiagen, catalogue number 941557). The TNAEs were indexed by PCR using the begomovirus DNA-A genome degenerate primers Accore/Avcore (Table 1; modified, Wyatt and Brown 1996) and DNA-beta satellite 
Table 1 List of primers used in PCR amplification of viral genomes

\begin{tabular}{|c|c|c|c|}
\hline Primer combinations & Primer Sequence $\left(5^{\prime}-3^{\prime}\right)$ & Cycling Parameters ${ }^{\mathrm{a}}$ & Product size (bp) \\
\hline Avcore & GCCHATRTAYAGRAAGCCMAGRAT & \multirow{2}{*}{$\begin{array}{c}95^{\circ} \mathrm{C} 20 \mathrm{~s}, 53{ }^{\circ} \mathrm{C} 20 \mathrm{~s} \text { and } 72{ }^{\circ} \mathrm{C} \text { for } \\
40 \mathrm{~s} \text { ( } 35 \text { cycles), } 72{ }^{\circ} \mathrm{C} 5 \text { min }\end{array}$} & \multirow[t]{2}{*}{579} \\
\hline Accore & GGRTTDGARGCATGHGTACANGCC & & \\
\hline CLCuGV705F & ACTCATCGTACTGGAAAGCG & \multirow{2}{*}{$\begin{array}{c}95^{\circ} \mathrm{C} 20 \mathrm{~s}, 55^{\circ} \mathrm{C} 20 \mathrm{~s} \text { and } 72{ }^{\circ} \mathrm{C} \text { for } \\
40 \mathrm{~s}(20 \text { cycles }), 72{ }^{\circ} \mathrm{C} 5 \mathrm{~min}\end{array}$} & \multirow[t]{2}{*}{1900} \\
\hline CLCuGV2507R & AGCACAGCTTCAAACAAGAAATAT & & \\
\hline CLCuGV2637F & TGTTGGGAGGAGCCATTGAC & \multirow{2}{*}{$\begin{array}{c}95^{\circ} \mathrm{C} 15 \mathrm{~s}, 55^{\circ} \mathrm{C} 15 \mathrm{~s} \text { and } 72{ }^{\circ} \mathrm{C} \\
\text { for } 45 \mathrm{~s}(35 \text { cycles }), 72{ }^{\circ} \mathrm{C} 60 \mathrm{~s}\end{array}$} & \multirow[t]{2}{*}{371} \\
\hline CLCuGV262R & GCGAGCATACAACGGAAACC & & \\
\hline CLCuGV29F & GATGTCCAATCAGAACGCGC & \multirow{2}{*}{$\begin{array}{c}95{ }^{\circ} \mathrm{C} 15 \mathrm{~s}, 55^{\circ} \mathrm{C} 15 \mathrm{~s} \text { and } 72{ }^{\circ} \mathrm{C} \\
\text { for } 45 \mathrm{~s}(35 \text { cycles }), 72{ }^{\circ} \mathrm{C} 60 \mathrm{~s}\end{array}$} & \multirow[t]{2}{*}{548} \\
\hline CLCuGV606R & CCCACTTCCCTTGGTCACAT & & \\
\hline CLCuGV2315F & CCCCATTCCAGTGTGTCTCC & \multirow{2}{*}{$\begin{array}{c}95{ }^{\circ} \mathrm{C} 15 \mathrm{~s}, 55^{\circ} \mathrm{C} 15 \mathrm{~s} \text { and } 72{ }^{\circ} \mathrm{C} \\
\text { for } 45 \mathrm{~s}(35 \text { cycles }), 72{ }^{\circ} \mathrm{C} 60 \mathrm{~s}\end{array}$} & \multirow[t]{2}{*}{569} \\
\hline CLCuGV78R & GCGCGTTCTGATTGGACATC & & \\
\hline
\end{tabular}

${ }^{\mathrm{a}}$ All reactions were incubated at $95^{\circ} \mathrm{C}$ for 1 min prior to cycling through incubations steps as described above

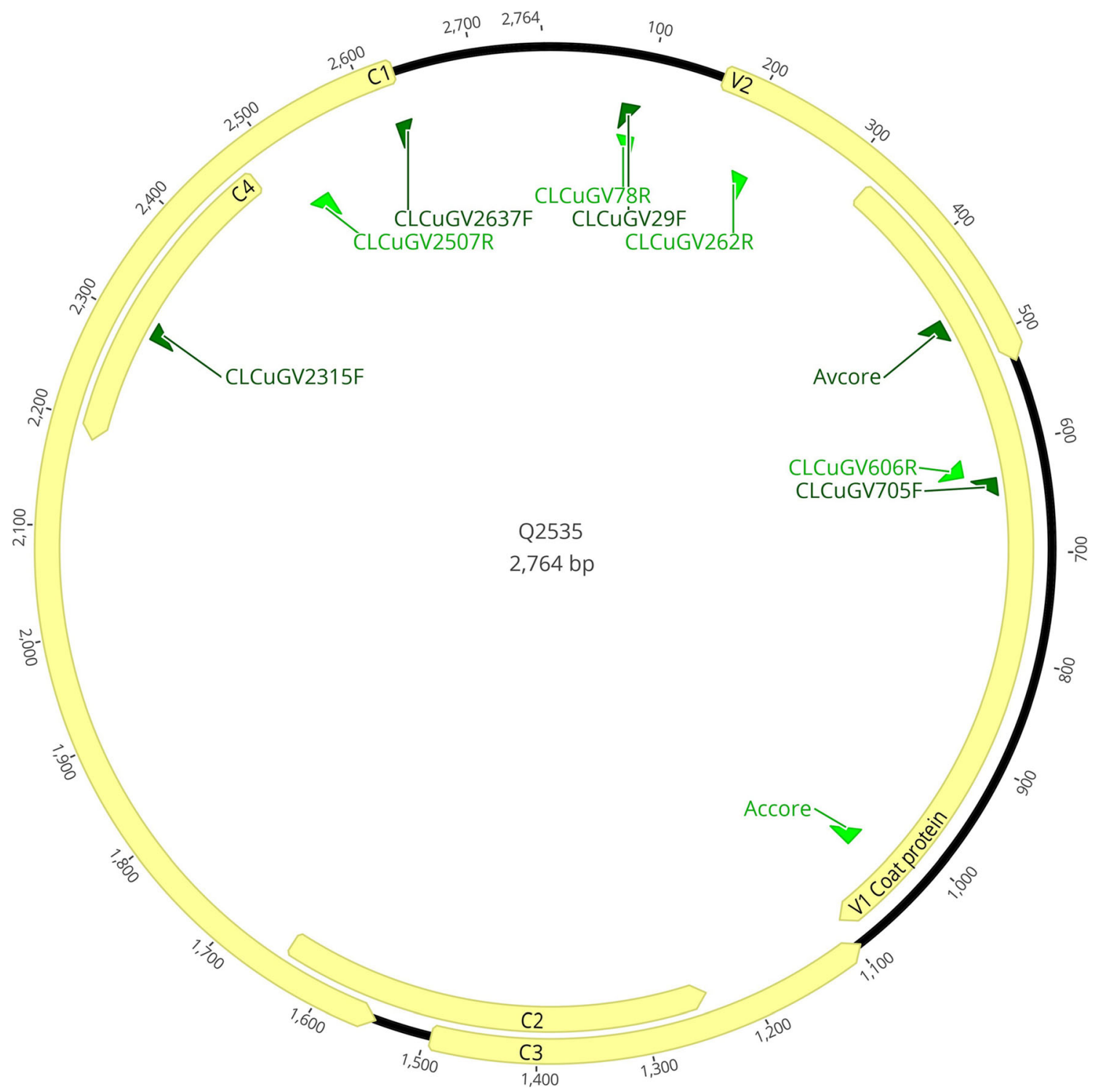

Fig. 1 Genome map of cotton leaf curl Gezira virus DNA-A isolate Q2535 showing location of primers used in genome walking 


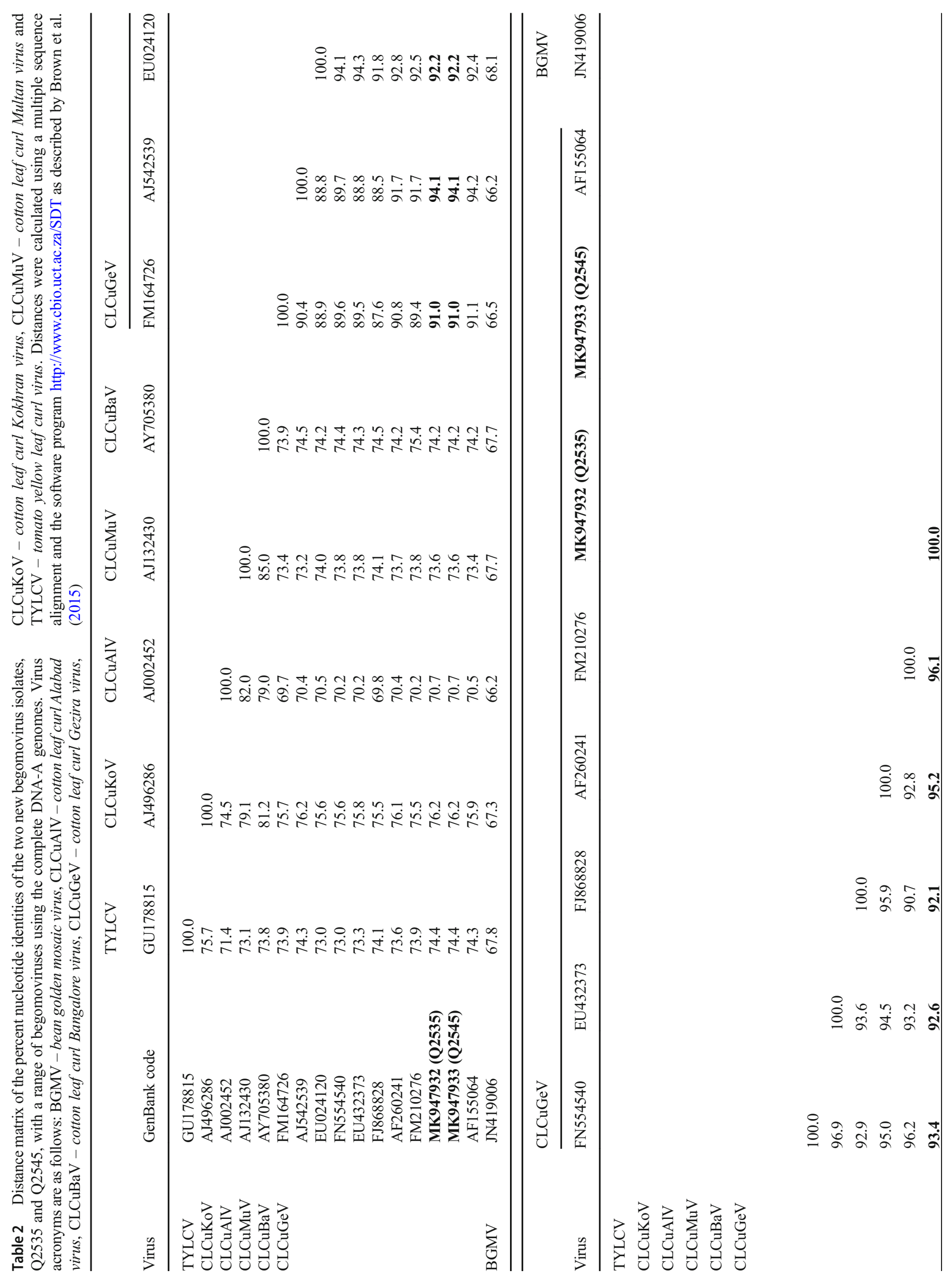




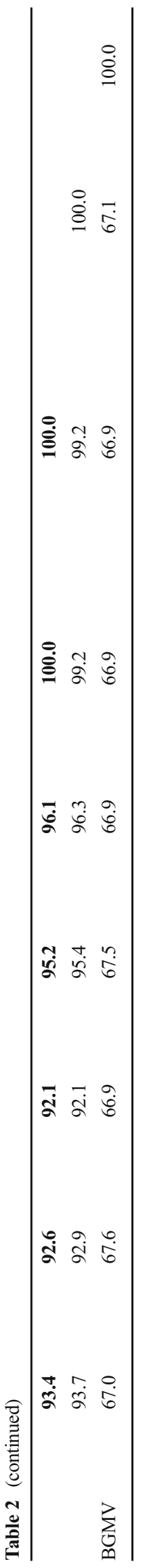

primers $\beta 01 / \beta 02$ (Briddon et al. 2002). The ca. $600 \mathrm{bp}$ amplicon expected for the DNA-A PCR was amplified from several samples. This included Q2517, Q2521, Q2535 and Q2545. The remaining samples Q2537, Q2539, Q2540, Q2541 and Q2542, tested negative for DNA-A by PCR. All samples tested negative using the $\beta 01 / \beta 02$ primers and lacked the typical severe $\mathrm{CLCuD}$ symptoms of leaf rolling, cupping and enations (Amin et al. 2011), thus indicating an absence of a DNA-beta satellite molecule. Amplification of circular genome components from the samples was attempted using rolling-circle amplification techniques, however, these were unsuccessful due to the effect of gamma-irradiation of samples required as a post-entry quarantine treatment for their importation into Australia.

DNA-A amplicons were obtained from four samples which were sequenced and analysed by BLASTN (National Centre for Biotechnology Information) to give putative virus identifications. Amplicons from two of the samples were identical to $\mathrm{CLCuGeV}$ and the amplicons from the remaining two sample were identical to squash leaf curl virus (SqLCV) in BLASTN searches. GenBank accession references for the SqLCV isolates are Q2517 - MN422079 and Q2521 - MN422078. The GenBank accession references of the two $\mathrm{CLCuGeV}$ isolates are of their full DNA-A genomes as described below (Q2535 GenBank MK947932 and Q2545 - MK947933).

As CLCuGeV has not previously been reported from melon and capsicum, further work was done to confirm the virus presence in these two samples. Sequence of full-length DNAA was achieved by sanger sequencing of PCR amplicons for the samples, Q2535 and Q2545. The primer pair 705F/2507R was used first and generated $1765 \mathrm{bp}$ of sequence, overlapping the original Avcore/Accore sequence by $282 \mathrm{bp}$. Sequence analyses and additional primers were designed using the Geneious Bioinformatics software package (Geneious). The newly designed primers were used to amplify and sequence the remaining DNA-A component from freshly prepared TNAEs (Table 1, Fig. 1). Cycling parameters for the different PCRs are listed in Table 1 and reactions contained $5 \mathrm{pmol}$ of forward and reverse primer, $1.75 \mathrm{mM} \mathrm{MgCl}_{2}$, $100 \mu \mathrm{M}$ dNTPS, and 0.2 U MangoTaq Polymerase (Bioline) in a total volume of $25 \mu \mathrm{l}$. The full DNA-A nucleotide sequence of the two isolates (Q2535 - GenBank MK947932 and Q2545 - MK947933) were 100\% identical to each other and 99.5\% to CLCuGeV (GenBank AF155064) by BLASTN searches. Using the criteria set by Brown et al., (2015) which states the demarcation for begomovirus species is $<91 \%$ for full DNA-A nucleotide sequences the isolates are identified as CLCuGeV (Table 2). Translation of the full DNA-A sequences generated the expected ORFs in the expected order for $\mathrm{CLCuGeV}$ (Fig. 1).

As many of the samples had symptoms similar to that expected for a potyvirus, and not all tested positive for begomovirus, the samples were also indexed for potyvirus. This was done using 

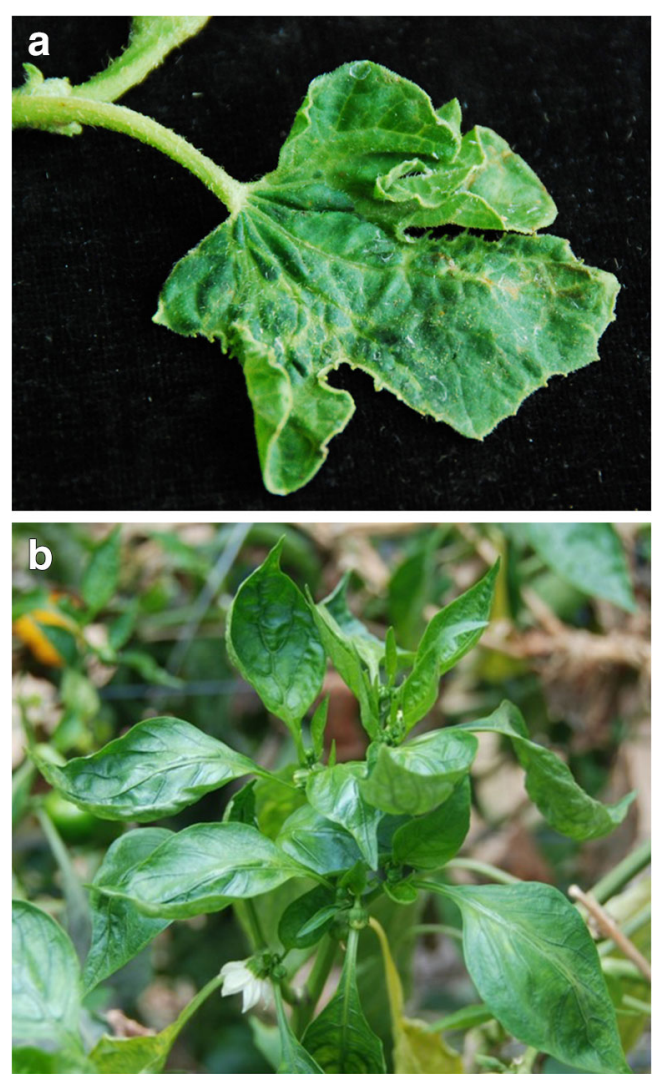

Fig. 2 a Symptoms of virus infection in the melon sample Q2545. The leaf distortion and mosaic is typical of a potyvirus infection and the sample was found to be co-infected with zucchini yellow mosaic virus and cotton leaf curl Gezira virus (b) Symptoms of virus infection in the capsicum sample Q2535. The upward cupping of the capsicum leaves is consistent with infection by a begomovirus

the primers U341/Poty1 (Langeveld et al. 1991; Gibbs and Mackenzie 1997) which amplify the 3'end of the coat protein and the 3'UTR. Seven of the nine samples tested positive in this assay and the amplicons sequenced to determine virus identity. Based on BLASTN searches using the partial genome sequences, zucchini yellow mosaic virus (ZYMV), was detected in three of the melon samples (Q2540, Q2542 and Q2545) and the squash sample (Q2517), papaya ringspot virus (PRSV) was detected in the fourth melon sample (Q2541) and potato virus $Y$ (PVY) was detected in the chilli sample (Q2537). The GenBank accession references for ZYMV are Q2540 - MN422075, Q2542 - MN422077, Q2545 - MK981542 and Q2517 - MN422073, for PRSV Q2541 - MN422076 and for PVY Q2537 - MN422074.

The symptoms observed in the samples of these new hosts of CLCuGeV are shown in Fig. 2. The melon sample, Q2545, had symptoms more typical of a potyvirus infection (Fig. 2a) and was confirmed co-infected with ZYMV. The presence of the potyvirus has masked any potential begomovirus induced symptoms. Further work with a single virus infection is required to elucidate what symptoms $\mathrm{CLCuGeV}$ causes in melon, if any. The capsicum sample, Q2535, was from a plant with upward leaf cupping (Fig. 2b), typical of a begomovirus infection, although not as severe as expected for co-infection with a DNA-beta satellite. As only one capsicum plant with these symptoms was sampled, again further work is needed to determine if this symptom was induced by $\mathrm{CLCuGeV}$ infection.

This is the first report of $\mathrm{CLCuGeV}$ infecting melon and capsicum which expands the known host range for the virus. This report also furthers the research on genetic diversity of begomoviruses in Egypt (Abdel-Salam et al. 2016).

Acknowledgements We thank the Australian Sub-committee on Plant Health Diagnostics and the Cotton Research and Development Corporation for research funding.

\section{References}

Abdel-Salam AM (1999) Isolation and characterisation of a whiteflytransmitted geminivirus associated with the leaf curl and mosaic symptoms on cotton in Egypt. Arab J Biotechnol 2:193-218

Abdel-Salam AM, Mujaddad-U M, El-Saghir SM (2016) Genetic diversity, natural host range and molecular pathogenesis of begomovirusassociated betasatellites in Egypt. Int J Virol 13:29-42. https://doi. org/10.3923/ijv.2017.29.42

Amin I, Hussain K, Akbergenov R, Yadav JS, Qazi J, Mansoor S, Hohn T, Fauquet CM, Briddon RW (2011) Suppressors of RNA silencing encoded by the components of the cotton leaf curl begomovirusbetasatellite complex. Mol Plant-Microbe Interact 24:973-983. https://doi.org/10.1094/MPMI-01-11-0001

Briddon RW (2003) Cotton leaf curl disease, a multicomponent begomovirus complex. Mol Plant Pathol 4:427-434. https://doi. org/10.1046/j.1364-3703.2003.00188.x

Briddon RW, Mansoor S, Bedford ID, Pinner MS, Saunders K, Stanley J, Zafar Y, Malik KA, Markham PG (2001) Identification of DNA components required for induction of cotton leaf curl disease. Virol 285:234-243. https://doi.org/10.1006/viro.2001.0949

Briddon RW, Bull SE, Mansoor S, Amin I, Markham PG (2002) Universal primers for the PCR-mediated amplification of DNA $\beta$. Mol Biotechnol 20:315-318. https://doi.org/10.1385/MB:20:3:315

Brown JK, Zerbini FM, Navas-Castillo J, Moriones E, Ramos-Sobrinho R, Silva JCF, Fiallo-Olivé E, Briddon RW, Hernández-Zepeda C, Idris A, Malathi VG, Martin DP, Rivera-Bustamante R, Ueda S, Varsani A (2015) Revision of Begomovirus taxonomy based on pairwise sequence comparisons. Arch Virol 160:1593-1619. https://doi.org/10.1007/s00705-015-2398-y

Cai JH, Xie K, Lin L, Qin BX, Chen BS, Meng JR, Liu YL (2010) Cotton leaf curl Multan virus newly reported to be associated with cotton leaf curl disease in China. New Disease Reports 20:29. https://doi. org/10.1111/j.1365-3059.2010.02266.x

Fauquet C, Briddon R, Brown J, Moriones E, Stanley J, Zerbini M, Zhou X (2008) Geminivirus strain demarcation and nomenclature. Arch Virol 153:783-821. https://doi.org/10.1007/s00705-008-0037-6

Gibbs AJ, Mackenzie AM (1997) A primer pair for amplifying part of the genome of all potyvirids by RT-PCR. J Virol Methods 63:9-16. https://doi.org/10.1016/S0166-0934(96)02103-9

Idris AM, Brown JK (2002) Molecular analysis of cotton leaf curl virusSudan reveals an evolutionary history of recombination. Virus Genes 24:249-256

Idris AM, Briddon RW, Bull SE, Brown JK (2005) Cotton leaf curl Gezira virus-satellite DNAs represent a divergent, geographically isolated Nile Basin lineage: predictive identification of a satDNA 
REP-binding motif. Virus Res 109:19-32. https://doi.org/10.1016/j. virusres.2004.10.002

Langeveld SA, Dore JM, Memelink J, Derks AFLM, van der Vlugt CIM, Asjes CJ, Bol JF (1991) Identification of potyviruses using the polymerase chain reaction with degenerate primers. J Gen Virol 72: 1531-1541. https://doi.org/10.1099/0022-1317-72-7-1531

Malathi VG, Radhakrishnan G, Varma A (2003) Cotton. In: Lobenstein G, Thottappilly G (eds) Virus and virus-like diseases of major crops in developing countries. Kluwer Academic Publishers

Mansoor S, Khan SH, Bashir A, Saeed M, Zafar Y, Malik KA, Briddon R, Stanley J, Markham PG (1999) Identification of a novel circular single-stranded DNA associated with cotton leaf curl disease in Pakistan. Virol 259:190-199

Mansoor S, Briddon RW, Bull SE, Bedford ID, Bashir A, Hussain M, Saeed M, Zafar Y, Malik KA, Fauquet C, Markham PG (2003) Cotton leaf curl disease is associated with multiple monopartite begomoviruses supported by single DNA- $\beta$. Arch Virol 148: 1969-1986. https://doi.org/10.1007/s00705-003-0149-y

Mansoor S, Zafar Y, Briddon RW (2006) Geminivirus disease complexes: the threat is spreading. Trends Plant Sci 11:209-212. https://doi.org/ 10.1016/S1360-1385(03)00007-4

Nateshan HM, Muniyappa V, Swanson MM, Harrison BD (1996) Host range, vector relations and serological relationships of cotton leaf curl virus from southern India. Ann Appl Biol 128:232-244. https:// doi.org/10.1111/j.1744-7348.1996.tb07319.x

Varma A, Malathi VG (2003) Emerging geminivirus problems: a serious threat to crop production. Ann Appl Biol 142:145-164. https://doi. org/10.1111/j.1744-7348.2003.tb00240.x

Wyatt SD, Brown JK (1996) Detection of subgroup III geminivirus isolates in leaf extract by degenerate primers and polymerase chain reaction. Phytopathology 86:1288-1293. https://doi.org/10.1094/ Phyto-86-1288 